\title{
Synthesis of silver nanoparticles by coastal plant Prosopis chilensis (L.) and their efficacy in controlling vibriosis in shrimp Penaeus monodon
}

\author{
Kathiresan Kandasamy • Nabeel M. Alikunhi • \\ Gayathridevi Manickaswami · Asmathunisha Nabikhan • \\ Gopalakrishnan Ayyavu
}

Received: 23 December 2011/ Accepted: 1 February 2012/Published online: 22 February 2012

(C) The Author(s) 2012. This article is published with open access at Springerlink.com

\begin{abstract}
The present work investigated the effect of leaf extract from coastal plant Prosopis chilensis on synthesis of silver nanoparticles using $\mathrm{AgNO}_{3}$ as a substrate and to find their antibacterial potential on pathogenic Vibrio species in the shrimp, Penaeus monodon. The leaf extract could be able to produce silver nanoparticles, as evident by gradual change in colour of the reaction mixture consisted of the extract and $1 \mathrm{mM} \mathrm{AgNO}_{3}$ to dark brown. The silver nanoparticles exhibited $2 \theta$ values corresponding to the presence of silver nanocrystal, as evident by X-ray diffraction spectrum. The peaks corresponding to flavanones and terpenoids were found to be stabilizing agents of the nanoparticles, as revealed by Fourier transform infrared spectroscopy. The size of silver nanoparticles ranged from 5 to $25 \mathrm{~nm}$ with an average of $11.3 \pm 2.1 \mathrm{~nm}$ and was mostly of spherical in shape, as confirmed by transmission electron microscopy. The silver nanoparticles were found to inhibit Vibrio pathogens viz., Vibrio cholerae, V. harveyi, and $V$. parahaemolyticus and this antibacterial effect was better than that of leaf extract, as proved by disc diffusion assay. The nanoparticles were then tested in the shrimp Penaeus monodon challenged with the four species of Vibrio pathogens for 30 days. The shrimps fed with silver nanoparticles exhibited higher survival, associated with immunomodulation in terms of higher haemocyte counts, phenoloxidase and antibacterial activities of haemolymph of $P$. monodon which is on par with that of control. Thus, the present study proved the possibility of
\end{abstract}

K. Kandasamy $(\bowtie) \cdot$ N. M. Alikunhi · G. Manickaswami · A. Nabikhan - G. Ayyavu

Centre of Advanced Study in Marine Biology, Annamalai

University, Parangipettai 608502, Tamil Nadu, India

e-mail: kathirsum@rediffmail.com using silver nanoparticles produced by coastal Prosopis chilensis as antibacterial agent in controlling vibriosis.

Keywords Silver nanoparticles - Shrimp aquaculture · Vibriosis · Prosopis chilensis · Penaeus monodon

\section{Introduction}

Aquaculture is an important economic activity all over the world. In 1970, aquaculture formed 3.9\% of the total global production by weight which increased to $27.1 \%$ in 2000 . In 2004, aquaculture formed almost a one-third of the global production by weight, which is $32.4 \%$ (FAO 2007). About $47 \%$ of consumed fish and other seafood originate from aquaculture (FAO 2009). Aquaculture production has been increasing at an average rate of 3.9\% in developed countries while at an average of $8.2 \%$ in developing countries (FAO 2007). In Asia, shrimp production is predominantly focused on the black tiger prawn, Penaeus monodon due to its excellent taste, universal appeal and high market and export market value. The intensified farming of $P$. monodon throughout the world has led to the outbreak of diseases which impede the aquaculture industry in many countries (FAO 2010).

Vibriosis is one of the major diseases caused in the aquatic organisms especially in shrimp in all seasons and can cause seafood-borne gastroenteritis in humans (Sujeewa et al. 2009). The term vibriosis refers to diseases associated with bacteria of the genus Vibrio. They are the natural inhabitants of estuarine and marine environments, well known for causing vibriosis in fish worldwide (Schäperclaus 1986). The prevention of vibriosis is a major challenge to aquafarming. There are various measures to prevent the entry of pathogenic microbes. However, techniques like sterilization to get rid of adherent microflora 
disturb the balance of microbial communities and favour exponential growth of opportunistic bacteria (Baticados et al. 1990). The usage of antibiotics is another option, but the indiscriminate use of antibiotics has led to an increased number of antibacterial-resistant bacteria, and ultimately compromises the treatment of bacterial infections in humans (Gersema and Helling 1986; McDermott et al. 2002). The emergence of multi-resistant bacteria to antibacterial drugs has increased the need for new alternatives against microbial pathogens (Tollefson and Miller 2000).

Prosopis chilensis is a small, deciduous, usually spiny, freely branched tree found commonly in the arid and semiarid regions. They possess the ability to grow in seawater salinity. The tree is drought hardy and it regenerates rapidly. Hence it has been observed as common weed, coming up singly and in groups in various habitats. The species is indigenous to the Pacific coast of Peru, Bolivia, Chile, and eastern Argentina. The pods, beans and leaves are browsed and used as fodder, whereas the wood is used as fuel in many regions of the world. The sweet pods are eaten or used to make a drink. The tree is also planted for shade and thornless varieties are used as ornamentals. They are also known as a candidate for erosion control and soil stabilization in arid lands, due to its deep rooting habit (Orwa et al. 2009). The ability of this plant to withstand the extreme climatic condition might be due to the presence unique biological compounds. This assumption prompted us to select this particular plant as our experimental plant for silver nanoparticle synthesis.

Silver nanoparticles have been tested in various fields of biological sciences viz. drug delivery, wound treatment, binding with HIV gp120 protein (Elchiguuerra et al. 2005). It is well known that silver ion and silver-based compounds are highly toxic to microorganisms (Slawson et al. 1992) and they are used as antibacterial compounds (Knetsch and Koole 2011; Jain and Pradeep 2005; Son et al. 2004; Li et al. 2005; Baker et al. 2005; Shrivastava et al. 2007; Pal et al. 2007; Kathiresan et al. 2010). Use of plants for synthesis of nanoparticles could be advantageous over other environmentally benign biological processes as this eliminates the elaborate process of maintaining microbial cell cultures. In this context, the present investigation was designed to synthesise silver nanoparticles using coastal plant Prosopis chilensis, and to evaluate antivibrio activity of the nanoparticles against shrimp pathogens.

\section{Materials and methods}

\section{Chemicals}

All analytical reagents and media components were purchased from Hi-media (Mumbai, India) and Sigma chemicals (St. Louis, USA).
Synthesis of silver nanoparticle

Leaf extract was made from Prosopis chilensis L. (Fabaceae) collected from Parangipettai (Lat.11 ${ }^{\circ} 29^{\prime} \mathrm{N}$; Long. $79^{\circ} 46^{\prime} \mathrm{E}$ ) in the south east coast of India. Fresh leaves weighing $20 \mathrm{~g}$ were washed thoroughly with distilled water, extracted in $100 \mathrm{~mL}$ of boiling distilled water for $5 \mathrm{~min}$. For reduction of $\mathrm{Ag}^{+}$ions, $5 \mathrm{~mL}$ of leaf broth was added to $45 \mathrm{ml}$ of $10^{-3} \mathrm{M}$ aqueous $\mathrm{AgNO}_{3}$ solution. The reduction of $\mathrm{Ag}^{+}$ions was monitored by visual observation and measuring the absorbance of the solution in a range of wavelengths ranging from 300 to 700 using UV-visible spectrophotometer (Elico, Chennai).

\section{Characterization of silver nanoparticles}

The X-ray diffraction (XRD) measurement of silver nanoparticles synthesized by leaf extract was carried out using $\mathrm{Cu}-\mathrm{K} \alpha$ radiation source in powder diffractometer (PANalytical X'per PRO model X-ray diffractometer), on films of the solutions drop coated onto glass substrate on the instrument operating at a voltage of $50 \mathrm{kV}$ and a current of $30 \mathrm{~mA}$.

For Fourier Transform Infrared spectroscopy (FTIR) measurement, the following method was adopted. The silver nanoparticles were synthesized after $24 \mathrm{~h}$ of reaction with leaf extract, centrifuged at $10,000 \mathrm{rpm}$ for $15 \mathrm{~min}$, and the pellet was redispersed in sterile distilled water to get rid of any uncoordinated biological molecules. The centrifugation and redispersion in sterile distilled water was repeated three times to ensure better separation of free entities from the metal nanoparticles. The purified pellets were then dried and the powder was subjected to FTIR spectroscopy measurement (Paragon 500, Perkin ElmerRX1 spectrophotometer) in the diffuse reflectance mode at a resolution of $4 \mathrm{~cm}^{-1}$ in $\mathrm{KBr}$ pellets.

After $24 \mathrm{~h}$ of incubation, the reaction mixture was used to form a film of silver nanoparticles on carbon-coated copper TEM grids (Electron microscopy sciences, Hatfield, PA 19440) and analyzed under a transmission electron microscope (JOEL, JEM $100 \mathrm{SX}$ ) at a voltage of $120 \mathrm{kV}$.

Antibacterial properties of silver nanoparticles

\section{In vitro antibacterial studies}

The antibacterial assay was done by disc-diffusion assay method (Casida 1986). In this method, $50 \mu \mathrm{l}$ of silver nanoparticle prepared from leaf extract, was mixed in $1 \mathrm{ml}$ of distilled water and applied to sterile paper discs of $5 \mathrm{~mm}$ diameter (Hi media, India). Similarly, $50 \mu \mathrm{l}$ water extract of Prosopis chilensis mixture was applied to sterile paper discs to find out the activity of the plant extract. Sterile 
paper disc without any treatment was used as control. The discs were then placed on Muller Hinton agar, swabbed with different test pathogens such as Vibrio cholera, V. harveyi, and $V$. parahaemolyticus which was prepared at a concentration of $10^{6} \mathrm{bacteria} / \mathrm{ml}$ in nutrient broth. These bacterial strains were isolated earlier from infected shrimps and identified. The plates were incubated at $30^{\circ} \mathrm{C}$ for overnight. The zones of inhibition were measured after the $24 \mathrm{~h}$ of incubation.

\section{In vivo antibacterial studies}

A batch of healthy adults Penaeus monodon (mean body weight $15.6 \pm 1.5 \mathrm{~g}$ ) were brought to the laboratory from a shrimp farm located at Parangipettai. The shrimps, after 7 days of quarantine, were transferred to plastic tanks of $50 \mathrm{~L}$ capacity and acclimatized for a week. The experiment was conducted for 30 days in the laboratory conditions. Physico-chemical parameters such as salinity, $\mathrm{NH}_{3}-\mathrm{N}$, $\mathrm{NO}_{2}-\mathrm{N}, \mathrm{NO}_{3}-\mathrm{N}$ and dissolved oxygen were monitored regularly for the rearing water which is maintained at optimal levels by water exchange. The selected healthy shrimps were divided into four different groups. Each contained a total of 15 shrimps.

Group I: Control (without any treatment)

Group II: Fed with silver nanoparticles alone $(0.1 \mathrm{mg}$ of silver nanoparticles in $10 \mathrm{mg}$ of standard feed)

Group III: Added with Vibrio species mixture $\left(10^{6}\right.$ counts $/ \mathrm{ml})$ and fed with silver nanoparticles $(0.1 \mathrm{mg}$ of silver nanoparticles in $10 \mathrm{mg}$ of standard feed)

Group IV: Added with Vibrio species mixture $\left(10^{6}\right.$ counts $\left./ \mathrm{ml}\right)$

The animals in group I provided with standard feed without any addition were considered as control. The animals of group II and III were applied with silver nanoparticle solution by mixing it with the standard feed ( $0.1 \mathrm{mg}$ of silver nanoparticles in $10 \mathrm{mg}$ of standard feed) and air dried. The group II was applied with silver nanoparticles alone whereas group III was applied with silver nanoparticles and Vibrio species mixture. The Vibrio species mixture was made by culturing, $V$. cholerae, $V$. harveyi, and, V. parahaemolyticus in Zobell marine broth and cell biomass was harvested at the $18 \mathrm{~h}$ of incubation. Cells were separated by centrifugation at $7,500 \mathrm{~g}$ for $10 \mathrm{~min}$ at $4^{\circ} \mathrm{C}$ and mixed in water at a concentration of $10^{6}$ counts/ $\mathrm{ml}$. The animals in group IV were treated with Vibrio species mixture and were provided with standard feed alone. Feed was given twice daily ( 8 a.m. and 7 p.m.) for 2 days at a rate of $10-15 \%$ of body weight per day. The percentage of survival rate was monitored daily during days of the experiment by counting the number of the animals died. The immune parameters were assayed on the initial and after 30 days of experiment.
Haematological and immunological parameters

Haemolymph was collected from experimental shrimps aseptically from the rostral sinus using a sterile capillary tube having a diameter of $0.5 \mathrm{~mm}$ and pre-rinsed with anticoagulant, EDTA. The haemolymph was transferred to sterile microcentrifuge tubes containing the anticoagulant. Total haemocyte count (THC) was made using a haemocytometer and expressed as THC $\mathrm{ml}^{-1}$ haemolymph.

Phenoloxidase activity was measured spectrophotometrically using L-3, 4-dihydroxyphenylalanine as the substrate (Soderhall 1981). The dopachrome formed was measured at $495 \mathrm{~nm}$ and phenoloxidase activity was then expressed as the increase in absorbance per minute per $100 \mu \mathrm{l}$ haemolymph. The endobiotic assay was conducted using haemolymph $(50 \mu \mathrm{l})$ collected from different groups of experimental shrimps. The haemolymph was loaded on sterile paper discs and placed on a Muller Hinton agar plate, swabbed with bacterial strains (Vibrio cholerae, $V$. harveyi, and $V$. parahaemolyticus). The plates were incubated at $30^{\circ} \mathrm{C}$ for $18 \mathrm{~h}$ and diameter of the growth inhibition zones was measured.

\section{Statistical analysis}

Statistical analysis was performed using one way analysis of variance by SPSS software package (version 17.0), followed by Duncan's multiple range test (DMRT). Results are expressed as mean \pm standard deviation from six shrimps in each group.

\section{Results}

Synthesis of silver nanoparticles

The reaction mixture consisted of silver nitrate and leaf extract exhibited change of colour, as noted by visual observation. The plant extract incubated with silver nitrate at the beginning of the reaction is shown in Fig. 1a. After the incubation in dark, the colour of the reaction mixture showed gradual change into yellowish brown, with intensity increasing during the period of incubation and was finally turned to intense brown after $24 \mathrm{~h}$ of incubation (Fig. 1b). Control (without silver nitrate) showed no change in colour of the leaf extract. The colour intensity in terms of optical density of the reaction mixture was taken at different wavelengths ranging from 300 to $700 \mathrm{~nm}$ and found that the absorbance peak was at $420 \mathrm{~nm}$ (Fig. 2).

Characterization of silver nanoparticles

In order to confirm the nature of silver nanoparticles produced by coastal Prosopis chilensis, X-ray diffraction 

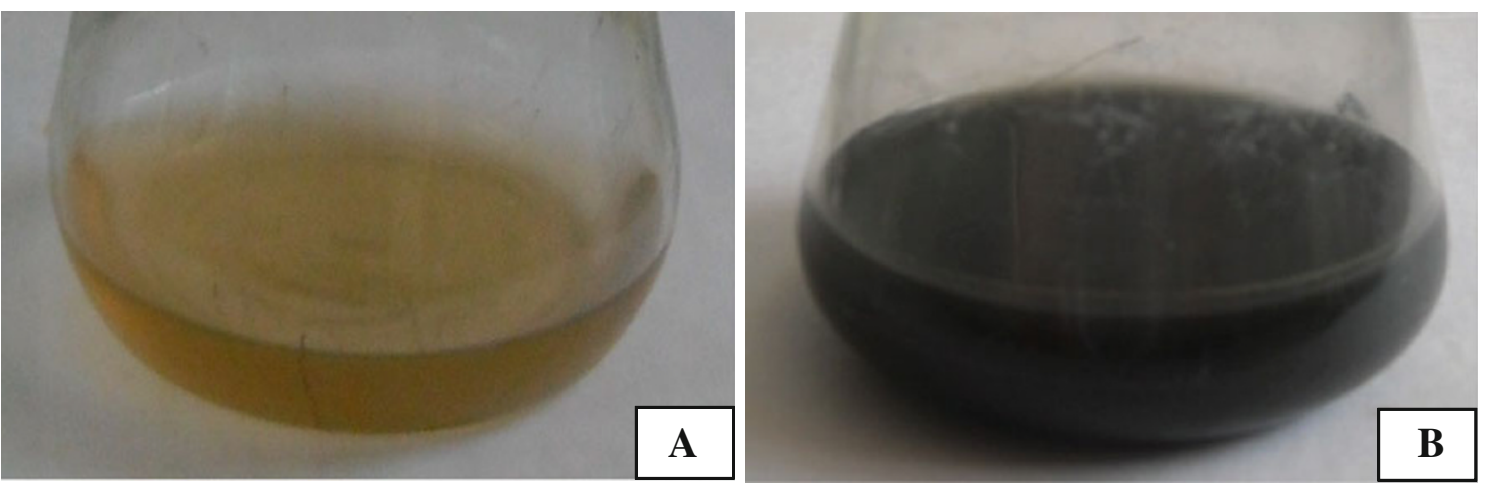

Fig. 1 Leaf extract of Prosopis chilensis with silver nitrate $(1 \mathrm{mM})$ : a at the beginning of the reaction and $\mathbf{b}$ after $24 \mathrm{~h}$ of reaction

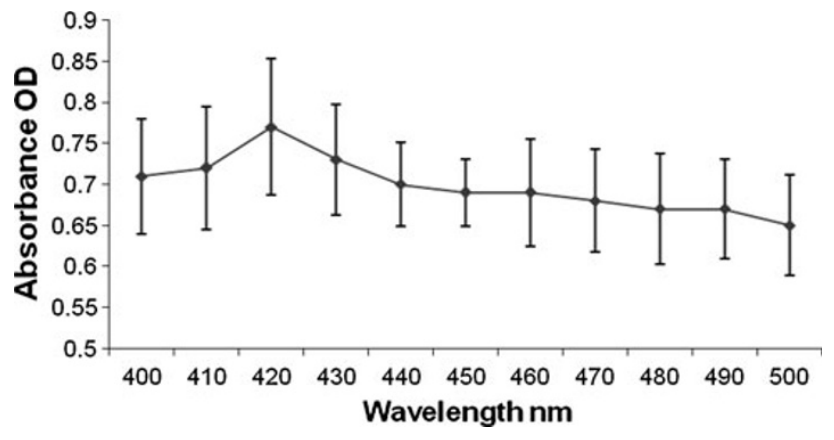

Fig. 2 Absorption spectrum for silver nanoparticles produced by coastal Prosopis chilensis at a range of wavelengths after $24 \mathrm{~h}$ of incubation (Each value is mean \pm standard deviation for three replicates)

pattern was found out as shown in Fig. 3. The XRD pattern showed intense peaks in the whole spectrum of $2 \theta$ value ranging from 20 to 80 with four intense peaks (111), (200), (220), (311) supporting strong Bragg reflections which correspond to the reflections of fcc silver. The silver nanoparticle was then analyzed for FTIR spectra. The Fig. 4 shows

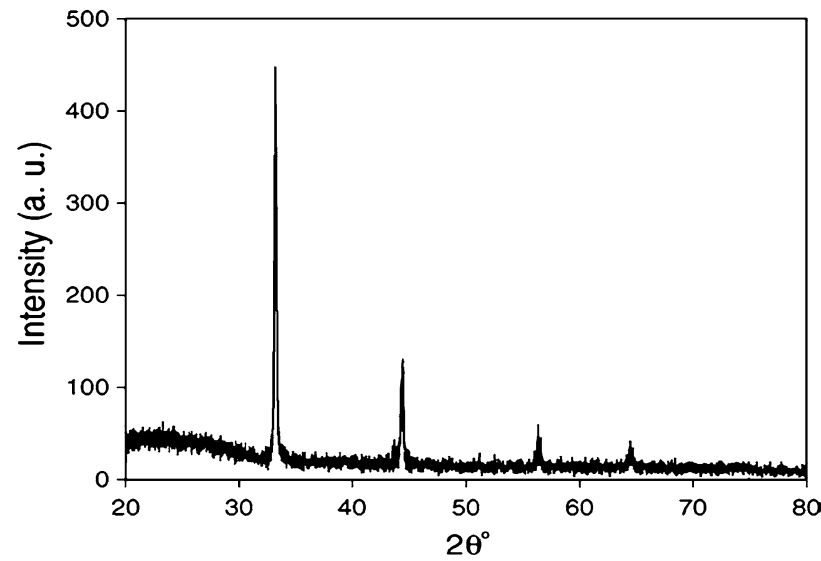

Fig. 3 XRD pattern of silver nanoparticles produced by leaf extract of coastal Prosopis chilensis

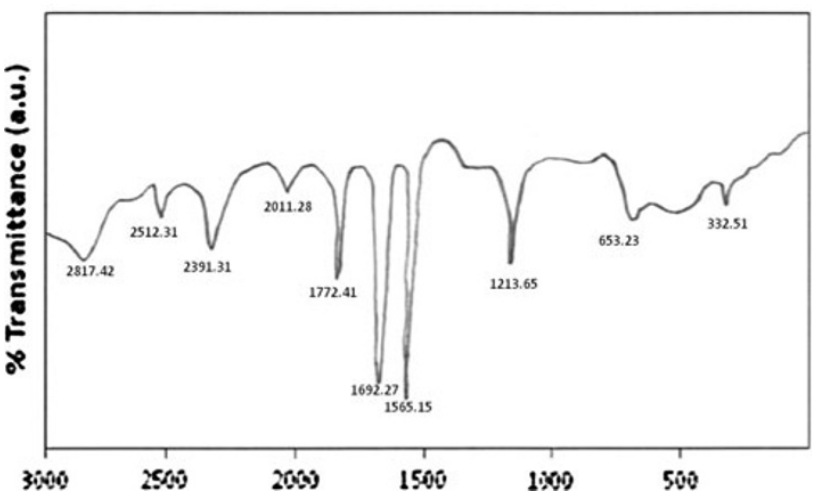

Fig. 4 FTIR spectrum of silver nanoparticles produced by leaf extract of coastal Prosopis chilensis

peaks at $1,565.15,1,692.27$ and $1,772.41(\mathrm{C}=\mathrm{C}$ groups or from aromatic rings). The shape and size of silver nanoparticles obtained after $24 \mathrm{~h}$ of incubation was then confirmed by TEM micrograph as presented in Fig. 5. The micrograph showed nanoparticles with variable shape, most of them

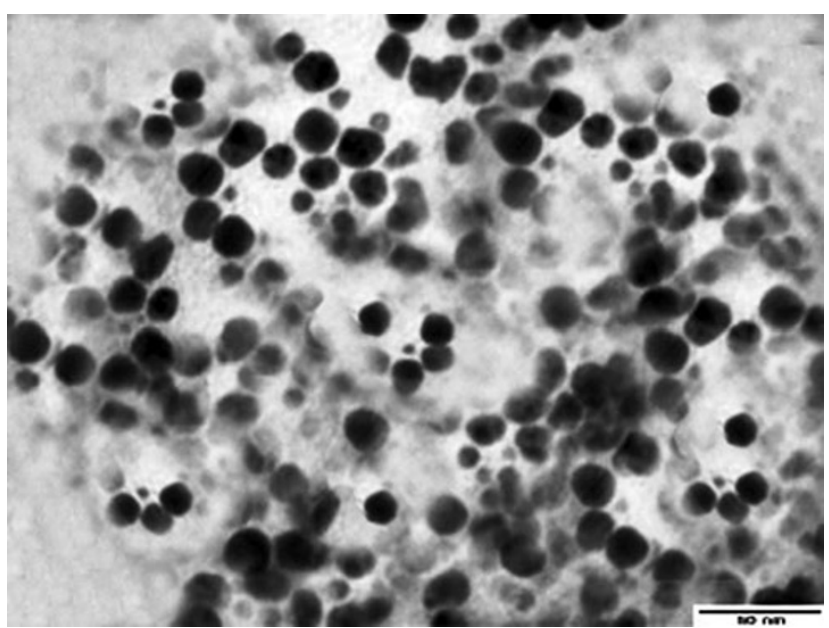

Fig. 5 TEM micrograph of silver particles synthesized by leaf extract of coastal Prosopis chilensis (scale bar $50 \mathrm{~nm}$ ) 
were of spherical in nature with varied size which ranged from 5 to $25 \mathrm{~nm}$ with an average size of $11.3 \pm 2.1 \mathrm{~nm}$. The particle size distribution histogram of silver nanoparticles from transmission electron microscope (TEM) analysis are given in the Fig. 6.

In vitro antibacterial studies

The discs applied with silver nanoparticle inhibited significantly all the vibrio pathogens $V$. cholerae, $V$. harveyi, and $V$. parahaemolyticus tested with inhibition zone of $22 \pm 3.5$, $16 \pm 2.7$ and $19 \pm 2.8 \mathrm{~mm}$, respectively. In contrast, there was no antibacterial activity in control and only a trace of activity with inhibition zone of less than $1 \mathrm{~mm}$ in the case of leaf extract (Table 1). Hence there was a statistically significant variation in antibacterial activity between each groups against the three pathogens tested $(P<0.05)$.

\section{Survival of shrimps}

After 30 days of experiment, the percent survival of shrimp with different groups is shown in Fig. 7. Shrimps fed with silver nanoparticles showed higher survival rate. The silver

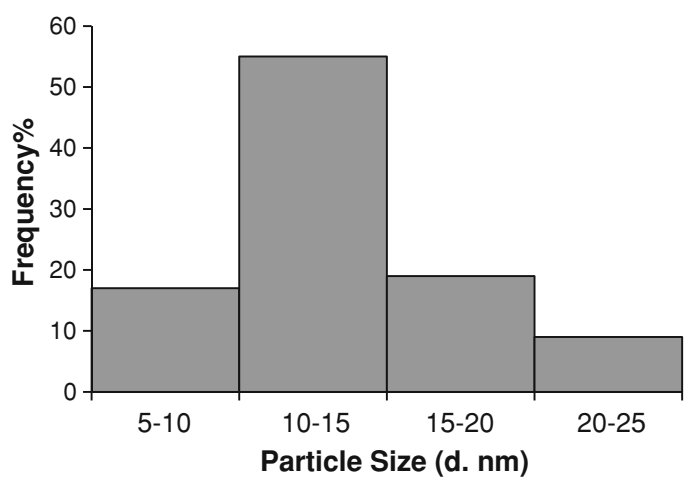

Fig. 6 Particle size distribution histogram of silver nanoparticles from transmission electron microscope (TEM) analysis

Table 1 Antibacterial activity of leaf extract of Prosopis chilensis and silver nanoparticles produced by the plant against vibrio pathogens on disc diffusion assay

\begin{tabular}{|c|c|c|c|}
\hline \multirow[t]{2}{*}{ Disc impregnated with } & \multicolumn{3}{|c|}{ Inhibition zone (mm) } \\
\hline & $\begin{array}{l}\text { V. } \\
\text { cholerae }\end{array}$ & $\begin{array}{l}V . \\
\text { harveyi }\end{array}$ & $\begin{array}{l}V . \\
\text { parahaemolyticus }\end{array}$ \\
\hline Leaf extract & $<1$ & $<1$ & $<1$ \\
\hline $\begin{array}{c}\text { Silver nanoparticles } \\
\text { produced by leaf } \\
\text { extract }+\mathrm{AgNO}_{3}\end{array}$ & $22 \pm 3.5$ & $16 \pm 2.7$ & $19 \pm 2.8$ \\
\hline Control & 0 & 0 & 0 \\
\hline
\end{tabular}

Values mean \pm standard deviation from three replicates in each group nanoparticle-fed shrimps when challenged against Vibrios exhibited a similar survival to that of control. In contrast the vibrios alone treated group showed total mortality at the end of the culture period (Fig. 7).

Immunomodulatory effect

The haemocyte counts and phenoloxidase were observed at higher levels in the shrimps fed with nanoparticles, exhibiting 92.8 and $185.7 \%$ increase of haemocytes and enzyme, respectively in 30 days of experiment (Tables 2 , 3 ). In this experimental shrimp, haemolymph showed high antibacterial activity of $4.3,8.4$ and $5.3 \mathrm{~mm}$ against $V$. cholerae, V. harveyi and V. parahaemolyticus, respectively (Table 4). There was a decline in haemocyte count by $38.2 \%$ and phenol oxidase by $18.6 \%$ and very low antivibrio activity of haemolymph in the shrimps challenged with vibrios. In contrast, the vibrios-challenged shrimps after feeding with silver nanoparticles exhibited a similar result which is on par with that of control.

\section{Discussion}

The modernization and intensification of aquaculture industry lead to outbreak of vibriosis resulting in huge loss of aquaculture industries throughout the world. The present study was designed to find the potential of silver nanoparticles, and to control vibriosis in the culture of P. monodon. The silver nanoparticles used for the present study were biosynthesized from Prosopis chilensis. Other plants such as Azadirachta indica (Neem) (Shankar et al. 2004), Medicago sativa (Alfalfa) (Gardea-Torresdey et al. 2003), Aloe vera (Chandran et al. 2006) and Emblica officinalis (amla, Indian Gooseberry) (Ankamwar et al. 2005) are already known for nanoparticle synthesis. The

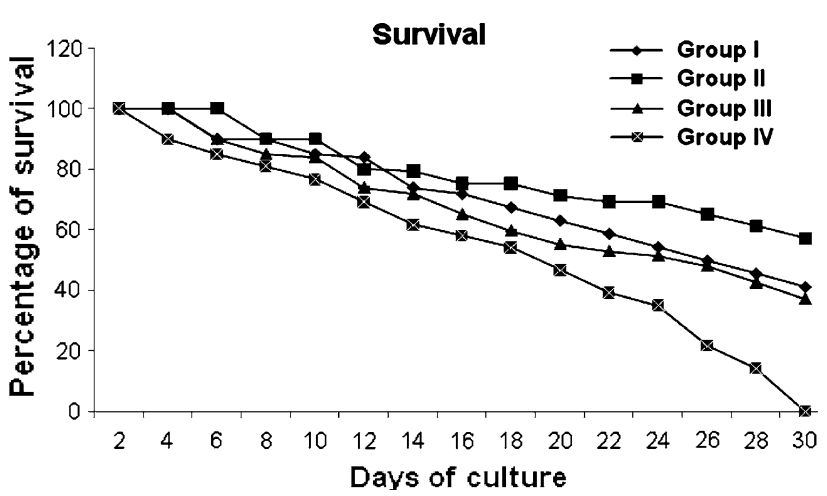

Fig. 7 Survival (\%) of Penaeus monodon in experimental shrimps: (I) control, (II) fed with silver nanoparticles, (III) fed with silver nanoparticles and challenged with vibrios, (IV) challenged with vibrios 
Table 2 Total haemocyte counts of shrimp, Penaeus monodon in different experimental groups

\begin{tabular}{|c|c|c|c|}
\hline \multirow[t]{2}{*}{ Groups } & \multicolumn{3}{|c|}{$\begin{array}{l}\text { Total haemocyte counts } \\
\left(\text { cells. } \mathrm{ml}^{-1} \text { ) }\right.\end{array}$} \\
\hline & 0 day & 30 days & $\%$ change \\
\hline Group 1 (control) & $80 \pm 5.5^{\mathrm{a}}$ & $103 \pm 6.5^{\mathrm{a}}$ & 28.8 \\
\hline Group 2 (fed with silver nanoparticles) & $83 \pm 5.1^{\mathrm{a}}$ & $160 \pm 9.8^{\mathrm{b}}$ & 92.8 \\
\hline Group 3 (fed with silver nanoparticles and challenged with vibrios) & $81 \pm 5.3^{\mathrm{a}}$ & $107 \pm 6.3^{\mathrm{a}}$ & 32.1 \\
\hline Group 4 (challenged with vibrios) & $89 \pm 3.4^{\mathrm{a}}$ & $55 \pm 2.4^{\mathrm{c}}$ & -38.2 \\
\hline
\end{tabular}

Values mean \pm standard deviation from three replicates in each group

Values not sharing a common superscript differ significantly $(P<0.05$, DMRT) between time intervals

Table 3 Phenol oxidase activity of shrimp, Penaeus monodon in different experimental groups

\begin{tabular}{|c|c|c|c|}
\hline \multirow[t]{2}{*}{ Groups } & \multicolumn{3}{|c|}{$\begin{array}{l}\text { Phenol oxidase activity } \\
\text { (OD at } 495 \mathrm{~nm} \text { ) }\end{array}$} \\
\hline & 0 day & 30 days & $\%$ change \\
\hline Group 1 (control) & $0.52 \pm 0.04^{\mathrm{a}}$ & $0.81 \pm 0.09^{\mathrm{b}}$ & 55.8 \\
\hline Group 2 (fed with silver nanoparticles) & $0.49 \pm 0.03^{\mathrm{a}}$ & $1.4 \pm 0.1^{\mathrm{c}}$ & 185.7 \\
\hline $\begin{array}{l}\text { Group } 3 \text { (fed with silver nanoparticles } \\
\text { and challenged with vibrios) }\end{array}$ & $0.51 \pm 0.04^{\mathrm{a}}$ & $0.77 \pm 0.06^{\mathrm{b}}$ & 50.9 \\
\hline Group 4 (challenged with vibrios) & $0.43 \pm 0.03^{\mathrm{a}}$ & $0.35 \pm 0.04^{\mathrm{a}}$ & -18.6 \\
\hline
\end{tabular}

Values mean \pm standard deviation from three replicates in each group

Values not sharing a common superscript differ significantly $(P<0.05$, DMRT) between time intervals

Table 4 Antibacterial activity of haemolymph of shrimp, Penaeus monodon

\begin{tabular}{llll}
\hline Groups & \multicolumn{2}{l}{ Inhibition zone $(\mathrm{mm})$} & \\
\cline { 2 - 4 } & V. cholerae & V. harveyi & V. parahaemolyticus \\
\hline Group 1 (control) & Trace & $2.3 \pm 0.04^{\mathrm{a}}$ & $1.2 \pm 6.5^{\mathrm{a}}$ \\
Group 2 (silver nanoparticles alone) & $4.3 \pm 0.03^{\mathrm{a}}$ & $8.4 \pm 0.03^{\mathrm{b}}$ & $5.3 \pm 9.8^{\mathrm{b}}$ \\
Group 3 (vibriosis + silver nanoparticles) & $1.4 \pm 0.04^{\mathrm{b}}$ & $2.3 \pm 0.04^{\mathrm{a}}$ & Trace \\
Group 4 (vibriosis) & 0 & 0 & 0 \\
\hline
\end{tabular}

Values mean \pm standard deviation from three replicates in each group

Values not sharing a common superscript differ significantly at $P<0.05$ (DMRT)

present study proved the biosynthesis of silver nanoparticles by the coastal Prosopis chilensis was successful. The synthesis of silver nanoparticles was noted by change in colour of leaf extract when added with $\mathrm{AgNO}_{3}$ and the colour change was due to excitation of surface plasmon vibrations, which indicated formation of silver nanoparticles (Mulvaney 1996).

It is important to know the exact nature of the silver particles formed by measuring the XRD-spectrum of the samples. The XRD-spectrum measured in this case resulted in four intense peaks (111), (200), (220) and (311) (Fig. 3), which are in agreement to the Braggs's reflection of silver nanocrystals (Lu et al. 2003). This confirmed that the silver nanoparticles formed by the extra cellular reduction of $\mathrm{Ag}+$ ions by Prosopis chilensis are crystalline in nature.

The FTIR measurement helps in finding out the possible biomolecules, responsible for capping and efficient stabilization of the metal nanoparticles. The FTIR spectra of nanoparticles (Fig. 4) exhibited peaks at $1,565.15 \mathrm{~cm}^{-1}$ (carboxylate anion stretch mode), 1,692.27 (amide I) and $1,772.41(\mathrm{C}=\mathrm{C}$ groups or from aromatic rings) suggesting the presence of flavanones, terpenoids and other methoxy compounds with minor peaks. The results of the present study reveal that flavanones or terpenoids adsorbed on the surface of metal nanoparticle, possibly by interaction through carbonyl groups or $\pi$-electrons in the absence of 
other strong ligating agents in sufficient concentration. It is also possible that the terpenoids play a role in reduction of metal ions by oxidation of aldehydic groups in the molecules to carboxylic acids, suggested by Shankar et al. (2004) while studying the synthesis of bimetallic $\mathrm{Au}-\mathrm{Ag}$ nanoparticles using Azadirachta indica leaf extract.

The present study attempted antibacterial activity of the silver nanoparticles and found that they inhibited the growth of all vibrio species tested (Table 1) in the in vitro studies. The in vivo experiment which was conducted on shrimp, Penaeus monodon for 30 days revealed that the shrimps fed with silver nanoparticles exhibited higher survival rate. These shrimps when challenged with vibrios showed a similar survival rate to that of control. In contrast, there was no survival of the shrimps challenged with vibrios at the end of the culture period (Fig. 7). Increasing Vibrio population in animal reduced the survival rate (Singh 1986; Hameed 1993). This reveals that the application of silver nanoparticles resulted in decreased counts of vibrios and hence the higher survival rate of the shrimps (Singh 1986; Hameed 1993).

The haemocytes have several important functions including prevention of haemolymph loss by coagulation, immobilization of pathogens by clotting, phagocytosis of foreign material, and hardening of cuticle (Soderhall and Smith 1986). Total haemocyte counts are sporadically used by shrimp disease diagnosticians (Lightner 1996). Haemocyte counts from $10^{4}$ to $10^{5}$ cell $/ \mathrm{mm}^{3}$ was maintained in healthy $P$. monodon, but when infected, there is a marked drop in counts (Supamattaya et al. 2005). In the present study also, there was a decline in haemocyte counts of shrimp group challenged with vibrios but counts increased in the shrimps fed with silver nanoparticles (Table 2). This is because the adverse effect caused by the vibrio, which was reduced by the application of silver nanoparticles.

The most well-studied haemolymph defensive system of crustaceans is phenoloxidase activity. Phenoloxidase catalyses the oxidation of the phenols to quinones, which subsequently polymerizes into a black-pigmented polymer, called melanin. Phenoloxidase is stored in its inactive form as prophenol oxidase (pro-PO), in haemocytes of crustaceans (Albores et al. 1993). Some of the intermediates in this melanization reaction are toxic to the microbial pathogens (Soderhall and Ajaxon 1982). In the present study, a prominent elevation in phenoloxidase level was observed in haemolymphs of the shrimps fed with silver nanoparticles (Table 3 ).

Broad-spectrum antibacterial activity is known in haemolymph of many crustaceans including species of lobsters, shrimp, crabs, isopods and stomatopods. Factors responsible for the antibacterial activity of haemolymph are collectively called as endobiotics which reside inside haemocytes and they are released after appropriate stimulation (Khoo et al. 1999). The present study also supported the above statement that the haemolymph showed antibacterial activity which was well pronounced when silver nanoparticle was applied (Table 4). Several mechanisms of inhibitory action of silver ions on microorganisms have been proposed. DNA loses its replication ability (Feng et al. 2000) and expression of ribosomal subunit proteins, as well as, some other cellular proteins and enzymes essential to ATP production becomes inactivated by silver ions (Yamanaka et al. 2005). It is hypothesized that silver primarily affects the function of membrane-bound enzymes, such as those in the respiratory chain (Bragg and Rainnie 1974; McDonnell and Russell 1999). The bactericidal activity of silver nanoparticles is due to interaction between the nanoparticles and constituents of the bacterial membrane which causes structural changes and damage to membranes, finally leading to cell death (Sondi and Salopek-Sondi 2004).

Silver-based antibacterial agents receive much attention because of the low toxicity of the silver ions to human cell (Williams et al. 1989; Berger et al. 1976), as well as, it is a long-lasting biocide with high thermal stability and low volatility. Another beneficial effect of using silver is due to the fact that pathogens cannot mutate to avoid its antibacterial effect. The development of resistance to antibacterial silver would be extremely rare because an organism would have to undergo simultaneous mutations in every critical function within a single generation to escape its influence. Spontaneous mutation is rare, occurring in only 1 per $10^{5}$ divisions, so the probability of multipledependent mutations occurring in the same generation of microbes is extremely small (Gibbins 2003). This problem is, however, common with antibiotics; bacteria carrying mutations causing antibiotic resistance pose a threat to human health, as they do not react to conventional treatment and may horizontally transfer this trait to other bacteria. The inhibition produced against the vibrio species would not cause any problem of antibiotic-resistant bacteria. Moreover, the fact that silver affects a number of cellular processes as well as the membrane integrity, while antibiotics specifically target one process. The bacteria mutate in such a way that the antibiotic is metabolized or removed from the cell. Also the specific target enzyme can be mutated, so that the sensitivity for the antibiotic decreases. In the case of silver, some of the resistance genes that have been identified seem to be involved in pumping silver out of the cell (Knetsch and Koole 2011; Cuin et al. 2007). Hence the silver nanoparticles are better antibacterial agents. In the present study, silver nanoparticles prevented vibriosis infection in the shrimp. The possible mode of action might be because silver nanoparticles inside the shrimp prevented the entry of pathogenic vibrios and hence the haemocyte counts and phenoloxidase 
activity of the shrimp were stimulated (Tables 2, 3). However, the detailed mechanism should be further investigated.

The present study revealed the application of silver nanoparticles as an alternative remedy for controlling vibriosis in the culture of $P$. monodon. However, the doubt about the silver accumulation in the shrimps remains uncertain and requires detailed investigations. Although the present study used a little concentration of silver nanoparticles, it is necessary to monitor the toxic levels in the shrimp tissue as the nanomaterials become more prevalent. However, estimations of environmentally likely concentrations of silver nanoparticle are so far not available (Griffitt et al. 2009). This reveals the need for further studies focused on understanding the mechanisms of nanoparticle toxicity in aquatic organisms as warranted by Griffitt et al. (2009). Hence, it requires detailed studies on risk assessment on silver accumulation in the animals and also on the economic viability in large scale application.

Acknowledgments The authors are thankful to the Director of CAS in Marine Biology and authorities of Annamalai University for providing all facilities.

Open Access This article is distributed under the terms of the Creative Commons Attribution License which permits any use, distribution, and reproduction in any medium, provided the original author(s) and the source are credited.

\section{References}

Albores V, Guzman MA, Ochoa JL (1993) An anticoagulant solution for haemolymph collection and prophenoloxidase studies of penaeid shrimp (Penaeus californiensis). Comp Biochem Physiol 106(A):299-303

Ankamwar B, Chaudhary M, Sastry M (2005) Synthesis and reactivity in inorganic metal. Org Nano Met Chem 35:19-27

Baker C, Pradhan A, Pakstis L, Pochan DJ, Shah SI (2005) Synthesis and antibacterial properties of silver nanoparticles. J Nanosci Nanotechnol 5:244-249

Baticados MCL, Lavilla-Pitogo CR, Cruz-Lacierda ER, de la Pena LD, Sunaz NA (1990) Studies on the chemical control of luminous bacteria Vibrio harveyi and V. splendidus isolated from diseased Penaeus monodon larvae and rearing water. Dis Aquat Org 9:133-139

Berger TJ, Spadaro JA, Chapin SE, Becker RO (1976) Electrically generated silver ions: quantitative effects on bacterial and mammalian cells. Antimicrob Agents Chemother 9:357-358

Bragg PD, Rainnie DJ (1974) The effect of silver ions on the respiratory chains of Escherichia coli. Can J Microbiol 20:883-889

Casida LE (1986) Industrial microbiology. Wiley Eastern Limited, New Delhi

Chandran SP, Chaudhary M, Pasricha R, Ahmad A, Sastry M (2006) Synthesis of gold nanotriangles and silver nanoparticles using Aloe vera plant extract. Biotechnol Prog 22:577-583

Cuin A, Massabni AC, Leite CQF, Sato DN, Neves A, Szpoganicz B, Silve MS, Bortoluzzi AJ (2007) Synthesis, X-ray structure and antimycobacterial activity of silver complexes with $\alpha$-hydroxycarboxylic acids. J Inorg Biochem 101:291-296

Elchiguuerra JL, Burt JL, Morones JR, Camacho-Bragado A, Gao X, Lara HH, Yacaman MJ (2005) Interaction of silver nanoparticles with HIV-1. J Nanobiotechnol 3:1477-3155

FAO (2007) Fishery Information, Data and Statistics Unit (FIDI) Fishery Statistical Collections. FAO, Rome

FAO (2009) Fisheries and Aquaculture Department. The state of world fisheries and aquaculture-2008, FAO, Rome

FAO (2010) Fisheries and Aquaculture Department. The state of world fisheries and aquaculture-2010, FAO, Rome

Feng QL, Wu J, Chen GQ, Cui FZ, Kim TM, Kim JO (2000) A echanistic study of the antibacterial effect of silver ions on Escherichia coli and Staphylococcus aureus. J Biomed Mater Res 52:662-668

Gardea-Torresdey L, Gomez E, Peralta-Videa JR, Parsons JG, Troiani H, Jose-Yacaman M (2003) Alfalfa sprouts: a natural source for the synthesis of silver nanoparticles. Langmuir 19:1357-1361

Gersema LM, Helling DK (1986) The use of subtherapeutic antibiotics in animal feed and its implications on human health. Drug Intell Clin Pharm 20:214-218

Gibbins B (2003) The antimicrobial benefits of silver and the relevance of micro lattice technology. Ost Wound Manag 49(6):5-6

Griffitt RJ, Hyndman K, Denslow ND, Barber DS (2009) Comparison of molecular and histological changes in Zebrafish gills exposed to metallic nanoparticles. Toxicol Sci 107(2):404-415

Hameed S (1993) A study of the aerobic heterotrophic bacterial flora of hatery-reared eggs, larvae and post-larvaeof Penaeus indicus. Aquaculture 117:195-204

Jain P, Pradeep T (2005) Potential of silver nanoparticle-coated polyurethane foam as an antibacterial water filter. Biotechnol Bioeng 90:59-63

Kathiresan K, Nabeel MA, SriMahibala P, Asmathunisha N, Saravanakumar K (2010) Analysis of antimicrobial silver nanoparticles synthesized by coastal strains of Escherichia coli and Aspergillus niger. Can J Microbiol 56:1050-1059

Khoo L, Robinette DW, Noga EJ (1999) Callinectin, an antibacterial peptide from blue crab, Callinectes sapidus, hemocytes. Mar Biotechnol 1:44-51

Knetsch MLW, Koole LH (2011) New strategies in the development of antimicrobial coatings: the example of increasing usage of silver and silver nanoparticles. Polymers 3:340-366

Li P, Li J, Wu C, Wu Q, Li J (2005) Synergistic antibacterial effects of lactam antibiotic combined with silver nanoparticles. Nanotechnology 16:1912-1917

Lightner DV (1996) Disease of cultured penaeid shrimp. In: Mcvey JP (ed) Handbook of mariculture. Crustacean Aquaculture, 2nd edn. CRC Press, Boca Raton, pp 393-486

Lu HW, Liu SH, Wang XL, Qian XF, Yin J, Jhu JK (2003) Silver nanocrystals by hyperbranched polyurethane-assisted photochemical reduction of $\mathrm{Ag}^{+}$. Mater Chem Phys 81:104-107

McDermott PF, Zhao S, Wagner DD, Simjee S, Walker RD, White DG (2002) The food safety perspective of antibiotic resistance. Anim Biotechnol 13:123-141

McDonnell G, Russell AD (1999) Antiseptics and disinfectants: activity, action, and resistance. Clin Microbiol Rev 12:147-179

Mulvaney P (1996) Surface plasmon spectroscopy of nanosized metal particles. Langmuir 12(3):788-800

Orwa C, Mutua A, Kindt R, Jamnadass R, Simons A (2009) Agroforestree database: a tree reference and selection guide version 4.0. (http://www.worldagroforestry.org/af/treedb/)

Pal S, Tak Y, Song JM (2007) Does the antibacterial effect of silver nanoparticle depend on the shape of the nanoparticle? A study of the gram-negative bacterium Escherichia coli. Appl Environ Microbiol 73:1712-1720 
Schäperclaus W (1986) Fish disease, vol 1. Amerind Publishing Co. Pvt. Ltd, New Delhi

Shankar SS, Rai A, Ahmad A, Sastry M (2004) Rapid synthesis of $\mathrm{Au}, \mathrm{Ag}$, and bimetallic $\mathrm{Au}$ core-Ag shell nanoparticles using Neem (Azadirachta indica) leaf broth. J Colloid Interface Sci 275:496-502

Shrivastava S, Bera T, Roy A, Singh G, Ramachandrarao P, Dash D (2007) Characterization of enhanced antibacterial effects of novel silver nanoparticles. Nanotechnology 18:1-9

Singh BI (1986) Studies on the bacteria associated with Penaeus indicus in a culture system. Ph.D. Thesis. Cochin University of Science and Technology, Cochin

Slawson RM, Van Dyke MI, Lee H, Trevor JT (1992) Germanium and silver resistance, accumulation and toxicity in microorganisms. Plasmid 27:73-79

Soderhall K (1981) Fungal cell wall $\beta-1-3$ glucans induce clotting and phenoloxidase attachment to foreign surfaces of crayfish haemocyte lysate. Dev Comp Immunol 5:565-573

Soderhall K, Ajaxon R (1982) Effect of quinines and melnin on mycelial growth of Aphanomyces sp., and extracellular protease of A. astaci, a parasite on crayfish. J Invert Pathol 59:105-109

Soderhall K, Smith VJ (1986) The prophenoloxidase activating system. In: Brehelin M (ed) Immunity in invertebrates. Springer, New York, pp 208-223
Son WK, Youk JH, Lee TS, Park WH (2004) Preparation of antimicrobial ultrafine cellulose acetate fibers with silver nanoparticles. Macromol Rapid Commun 25:1632-1637

Sondi I, Salopek-Sondi B (2004) Silver nanoparticles as antimicrobial agent: a case study on $E$. coli as a model for gram-negative bacteria. J Colloid Interface Sci 275:177-182

Sujeewa AKW, Norrakiah AS, Laina M (2009) Prevalence of toxic genes of Vibrio parahaemolyticus in shrimps (Penaeus monodon) and culture environment. Inter Food Res J 16:89-95

Supamattaya K, Bundit O, Boonyarapatlin M, Schatzmayr G, Chittiwan V (2005) Effects of ochratoxin A and deoxynivalenol on growth performance and immuno-physiological parameters in black tiger shrimp (Panaeus monodon). Songklanakarin J Sci Technol 27(1):91-99

Tollefson TL, Miller MA (2000) Antibiotic use in food animals: controlling the human health impact. J AOAC Int 83:245-254

Williams RL, Doherty PJ, Vince DG, Grashoff GJ, Williams DF (1989) The biocompatibility of silver. Crit Rev Biocompat 5:221-243

Yamanaka M, Hara K, Kudo J (2005) Bactericidal actions of a silver ion solution on Escherichia coli, studied by energy-filtering transmission electron microscopy and proteomic analysis. Appl Environ Microbiol 71:7589-7593 